\title{
The influence of Amylostereum areolatum diversity and competitive interactions on the fitness of the Sirex parasitic nematode Deladenus siricidicola
}

\author{
Hurley $\mathrm{BP}^{\mathrm{a}, \mathrm{b} *}$, Hatting $\mathrm{HJ}^{\mathrm{b}}$, Wingfield $\mathrm{MJ}^{\mathrm{b}}$, Klepzig $\mathrm{KD}^{\mathrm{c}}$, Slippers $\mathrm{B}^{\mathrm{b} . \mathrm{d}}$ \\ ${ }^{a}$ Department of Zoology and Entomology, University of Pretoria, Pretoria, 0002, South Africa; \\ brett.hurley@fabi.up.ac.za \\ ${ }^{\mathrm{b}}$ Forestry and Agricultural Biotechnology Institute (FABI), University of Pretoria, Pretoria, 0002, \\ South Africa; hardus.hatting@fabi.up.ac.za, mike.wingfield@,fabi.up.ac.za \\ ${ }^{\mathrm{c}}$ USDA Forest Service, Southern Research Station, Asheville, NC 28804, USA; kklepzig@fs.fed.us \\ ${ }^{\mathrm{d}}$ Department of Genetics, University of Pretoria, Pretoria, 0002, South Africa; \\ bernard.slippers@,fabi.up.ac.za
}

*Corresponding author:

Dr B.P. Hurley

FABI, Private Bag X20, Hatfield, Pretoria, 0028, South Africa

Phone: +27 12 4205822; Fax: +27 124203960

The Sirex noctilio (woodwasp) - Amylostereum areolatum (fungus) complex has caused substantial losses to pine industries in its introduced range. The nematode Deladenus siricidicola that parasitizes $S$. noctilio and feeds on A. areolatum is widely used as a biological control agent for $S$. noctilio, but not with consistent success. This variable success could be due to factors that influence the feeding and reproductive ability of the nematode on $A$. areolatum. We test two main hypotheses that emerge from this prediction. First, we compared the survival of $D$. siricidicola on the South African field strain and the Australian laboratory strain of $A$. areolatum, to examine a 
possible incompatibility between nematode and fungal strain. Second, we examined the competitive interactions of these two A. areolatum strains with two common sapstain fungi, Diplodia pinea and Ophiostoma ips, that occur in S. noctilio infested trees in South Africa. The effect of water potential on the outcome of these fungal interactions was also considered. The data showed that $D$. siricidicola survives at comparable levels on the two A. areolatum strains. Water potential of the media significantly influenced growth of the fungi and their ability to capture host resource in competitive interactions. Diplodia pinea competed increasingly better against $A$. areolatum with decreasing water potential. The results suggest that competitive interactions between $A$. areolatum and sapstain fungi could negatively influence the success of $D$. siricidicola, especially under conditions of lowered water potential.

Keywords: Amylostereum areolatum; Sirex noctilio; Deladenus siricidicola; sapstain fungi; biological control; competition.

\section{Introduction}

Amylostereum areolatum Boiden is a Basidiomycete fungus which has a mutualistic symbiotic relationship with siricid woodwasps (Cartwright, 1929; Talbot, 1977; Slippers et al., 2003). This fungus has been recorded in symbioses with the woodwasps Sirex noctilio Fabricius, Sirex juvencus (Linnaeus), Sirex nitobei Matsumura and Sirex cyaneus Fabricius (Bedding and Ackurst, 1978), and more recently with $S$. edwarsii Brullé and $S$. 'nitidus' (Nielsen et al., 2009). Of these symbioses, the $S$. noctilio $-A$. areolatum association is the best known. This is due to 
the fact that this insect is an invasive alien pest on Pinus spp. in many southern hemisphere countries where these trees are extensively grown in plantations.

Sirex noctilio attacks various conifer species, but predominantly Pinus species (Spradbery and Kirk, 1978). Sirex noctilio and A. areolatum in concert overcome the defences of the host tree and provide an ideal environment for the development of the fungus and wasp larvae (Coutts, 1969; Spradbery, 1973; Talbot, 1977). The fungus benefits by being dispersed by the wasp and introduced into a tree which has been weakened by the phytotoxic mucous injected by the wasp into the tree together with the eggs and fungus. In turn, the fungus is essential for the nutrition of the larvae (Coutts, 1969; Spradbery, 1973; Talbot, 1977).

Sirex noctilio is native to Eurasia, but has been accidentally introduced into many pine growing countries of the southern hemisphere during the course of the twentieth century (Miller and Clarke, 1935; Gilbert and Miller, 1952; Spradbery and Kirk, 1978; Tribe, 1995; Maderni, 1998; Klasmer et al., 1998; Iede et al., 1998; Hurley et al., 2007). In these countries, the $S$. noctilio $-A$. areolatum complex has resulted in major losses in pine plantations (Haugen, 1990; Maderni, 1998; Hurley et al., 2007). Most recently, S. noctilio was detected in North America (Hoebeke et al., 2005; de Groot et al., 2007). The threat that the $S$. noctilio - A. areolatum complex will pose to pine forests in North America is still uncertain, but Yemshanov et al. (2009) estimated the potential damage in Canada over the next 20 years to be as much as $\$ 254$ million per year.

The nematode Deladenus (= Beddingia) siricidicola Bedding, parasitic to $S$. noctilio, was discovered and described in the 1960s (Bedding, 1968). Deladenus siricidicola is extraordinary in having both a parasitic and mycetophagous life-cycle (Bedding, 1972). In the mycetophagous life-cycle, the nematodes feed on $A$. 
areolatum. In the vicinity of $S$. noctilio larvae, the high $\mathrm{CO}_{2}$ and low $\mathrm{pH}$ environment stimulates the parasitic life-cycle, where the nematodes parasitize the larvae. The nematodes do not kill the larvae, but develop and reproduce inside the larvae, and sterilize the eggs of the emerging female wasp. Infected female wasps lay nematodefilled eggs into new trees, thus spreading the nematode (Bedding, 1972; Bedding and Iede, 2005). Deladenus siricidicola feeds exclusively on $A$. areolatum in the mycetophagous life-cycle and can go through many generations in the absence of the parasitic life-cycle (Bedding, 1972; Spradbery and Kirk, 1978). The mycetophagous life-cycle takes approximately two weeks while the parasitic life-cycle follows the life-cycle of the wasp, which may vary from one to three years depending on the environment (Bedding, 1972).

Although complex, the biology of $D$. siricidicola makes it an ideal biological control agent for S. noctilio (Bedding and Iede, 2005). The nematode can be mass reared on cultures of $A$. areolatum in a short period of time and inoculated into $S$. noctilio-infested trees where they feed on $A$. areolatum in the tree until they locate $S$. noctilio larvae. Deladenus siricidicola has been released as a biological control agent in every southern hemisphere country where $S$. noctilio is a pest, often attaining parasitism levels between 70-100\% (Bedding and Akhurst, 1974; Iede et al., 1998; Tribe and Cillié, 2004; Carnegie et al., 2005). However, success with D. siricidicola has been variable (Hurley et al., 2007). In particular, inoculations with the nematode in the summer rainfall region of South Africa resulted in less than $10 \%$ parasitism (Hurley et al., 2007).

A possible explanation for the limited success of $D$. siricidicola inoculations is competition between $A$. areolatum and sapstain fungi in the wood (King, 1966). This hypothesis is based on the fact that competition for resources between fungi living on 
the same substrate is well known and involves primary resource capture or combat (Cooke and Rayner, 1984; Rayner and Webber, 1986; Boddy, 2000). For the $S$. noctilio system, sapstain fungi are often present in trees infested by this insect (B.P. Hurley, personal observation), and therefore A. areolatum and these fungi would need to compete for the same resource. Two sapstain fungi common in Pinus sp. in South Africa are Diplodia pinea (Desm.) Kick (formerly Sphareopsis sapinea (Fr.) Dyko and Sutton) and Ophiostoma ips (Rumb.) Nannf. (Wingfield and Swart, 1994; Zhou et al., 2001). Diplodia pinea is a latent pathogen associated with stress and wounds (Swart and Wingfield, 1991), and is commonly found in trees infested with S. noctilio. Similarly, O. ips is associated with the bark beetle, Orthotomicus erosus (Wollaston), which attacks stressed trees (Tribe, 1992; Zhou et al., 2001) and is also common in trees infested with $S$. noctilio. The limited spread of $A$. areolatum as a result of competition with these sapstain fungi could decrease the likelihood that the nematodes will survive until they find a fungal source or S. noctilio larvae.

Water availability (water potential) can influence the outcome of competitive interactions between fungal species (Shearer, 1995; Boddy, 2000). Studies on the competitive abilities of insect-associated fungi have shown that the primary and combative ability of the fungi, as well as water potential, influences the outcome of competitive interactions and can have important consequences for the success of the insect - fungus association (Klepzig and Wilkens, 1997; Klepzig et al., 2004; Bleiker and Six, 2009). The influence of moisture availability on inoculation success with $D$. siricidicola was suggested by Hurley et al. (2008), who showed that inoculation success was lowest in the drier top section of the tree.

The strain of $A$. areolatum that occurs together with $S$. noctilio is another factor that could influence inoculation success with $D$. siricidicola. Certain strains of 
A. areolatum from the field in Australia were found to be more preferable for rearing the nematode than others (R.A. Bedding personal communication in Slippers et al. (2001), authors, unpublished results). Further, Slippers et al. (2001) showed differences in the strain of $A$. areolatum present in South Africa and the strain imported from Australia, which is used to rear the nematode. An incompatibility between nematode and fungal strain could result in reduced nematode reproduction and consequently reduced parasitism of $S$. noctilio. Furthermore, the A. areolatum strain in South Africa could compete poorly with sapstain fungi compared to $A$. areolatum strains in other countries.

In this study we tested two hypotheses related to the fungal symbiont of $S$. noctilio that might influence the success of the nematode in biological control programs. First, we compared the survival and reproduction of different $D$. siricidicola populations on two different strains of $A$. areolatum, to determine if specificity on the fungus can influence reproductive fitness of the nematode. Second, we examined the competitive ability of the two A. areolatum strains with the sapstain fungi $D$. pinea and $O$. ips. Competitive interactions were examined in terms of primary resource capture and combat, and the influence that water potential has on the outcome.

\section{Materials and Methods}

2.1 Nematode sources and fungal strains

Two strains of $A$. areolatum were used in this study. The Australian laboratory strain (A. areolatum AUS) was sent from Australia with cultures of $D$. siricidicola in 
2003. This strain has been used for rearing nematodes for field release in South Africa since 2004. The South African field strain (A. areolatum KZN) was isolated from the field in 2007 and represents the fungus accidentally introduced with $S$. noctilio. The D. pinea strain used was isolated from P. patula in Vryheid, South Africa, in 2007. The $O$. ips strain was isolated from galleries of $O$. erosus on a Pinus sp., in Lothair, South Africa, in 2009.

All nematodes used in the study were of the Kamona strain of $D$. siricidicola (Bedding and Iede, 2005). Laboratory reared cultures from different nematode populations / sources were used, to examine whether the rearing history of the nematode might influence its survival on a specific $A$. areolatum strain. Four different nematode sources were used, namely BRA, ARG, KZN and KZN2. Two of the sources were from laboratory cultures in Brazil (BRA) and Argentina (ARG). The BRA and ARG sources were obtained in 2006 and have been reared on A. areolatum (AUS). The other two nematode sources were the original nematodes imported to South Africa from Australia in 2003, introduced into the field, and retrieved from parasitized wasps. The KZN source was retrieved in 2008 and subsequently grown on A. areolatum (AUS). The KZN2 source was retrieved from the field in 2007 and subsequently grown on $A$. areolatum $(\mathrm{KZN})$.

2.2 Nematode survival and reproduction assays

For the nematode survival and reproduction assays, Potato Dextrose Agar (PDA) (40 $\mathrm{g} \mathrm{l}^{-1}$ potato dextrose extract, $15 \mathrm{~g} \mathrm{l}^{-1}$ agar) in $90 \mathrm{~mm}$ Petri dishes and wheatrice medium in $500 \mathrm{ml}$ flasks ( $84 \mathrm{~g}$ wheat, $36 \mathrm{~g}$ brown rice, $80 \mathrm{ml}$ water) was used as a growth medium for $A$. areolatum. The flasks containing this medium were autoclaved 
at $121{ }^{\circ} \mathrm{C}$ for $30 \mathrm{~min}$, left to stand for 24 hours and then autoclaved again at $134{ }^{\circ} \mathrm{C}$ for 15 min. Flask cultures (see Bedding and Iede, 2005) were established for each of the four nematode sources, using A. areolatum (AUS). After approximately six weeks, nematodes were rinsed three times from each flask using tap water. Three samples were taken from the nematode sediment to estimate the total number of nematodes present. For each sample, one $\mathrm{ml}$ was removed from the sediment and diluted in $49 \mathrm{ml}$ of tap water, after which one $\mathrm{ml}$ was removed from this $50 \mathrm{ml}$ solution and the total number of nematodes in this sample were counted using a Petri dish with $0.5 \mathrm{~cm}^{2}$ grids, under a microscope at 20x magnification. The nematode-water solution was agitated before each sample was taken to ensure the suspension was well mixed. The average of the three sample counts was used to calculate an estimate for the number of nematodes in the flask.

PDA plates of either A. areolatum (AUS) or A. areolatum (KZN), where the fungus had grown over one third of the plate, were used to start the cultures for the nematode assays. Nematodes from each of the four sources were placed on plates with A. areolatum (AUS) and plates with $A$. areolatum (KZN). In total there were eight treatments of nematode source and fungal strain combination. Approximately 30000 nematodes were placed on each plate. The fungus was inoculated on one side and the nematodes were placed on the opposite side of the plate. The nematodes moved towards the fungus and after 12 hours two fungus-nematode plugs of approximately 3 x $3 \mathrm{~cm}$ were cut out and placed face-down on clean PDA plates. Flasks were kept at $23( \pm 2)^{\circ} \mathrm{C}$ and after two weeks, three fungus-nematode plugs of approximately the same size were removed from these new cultures and placed in flasks prepared with a wheat-rice medium. A plug of similar size, containing only the fungus was also placed in the flask, to ensure that the nematodes had sufficient food. After six weeks the 
nematodes were rinsed from the flasks and counted, as described above. For each treatment the 10 flasks which appeared to have the highest number of nematodes were counted.

\subsection{Fungal growth assays}

Growth media at different water potentials used for the fungal growth assays was based on previously published methods (Whiting and Rizzo, 1999; Klepzig et al., 2004). Media were prepared with the osmotic potentials of 0 (unamended MEA, $15 \mathrm{~g}$ $\mathrm{l}^{-1}$ agar, $10 \mathrm{~g} \mathrm{l}^{-1}$ malt extract), -5 MPa (MEA amended with $8.2 \mathrm{~g} \mathrm{l}^{-1} \mathrm{KCl}$ and $68.1 \mathrm{~g} \mathrm{l}^{-1}$ sucrose) and -10 MPa (MEA amended with $16.6 \mathrm{~g} \mathrm{l}^{-1} \mathrm{KCl}$ and $134.2 \mathrm{~g}^{-1} \mathrm{p}$ sucrose) in $90 \mathrm{~mm}$ Petri dishes. The growth of $A$. areolatum (AUS), A. areolatum (KZN), D. pinea and $O$. ips was examined on the three different media. A $0.5 \mathrm{~cm}$ diameter disc of fungus was placed face down at the centre of the plates. Mycelian growth was measured every second day from the fourth day after inoculation, for a total of 18 days after inoculation. Plates were sealed with Parafilm and maintained at $20{ }^{\circ} \mathrm{C}$ in the dark. Measurements were done using Image Tool v3.00 Microsoft ${ }^{\circledR}$ and the total area covered by the fungus was calculated.

\subsection{Fungal competition assays}

Competition between $A$. areolatum (AUS), A. areolatum (KZN), D. pinea and $O$. ips was examined on the same three media as used for the fungal growth assays using established techniques (Klepzig and Wilkens, 1997). A $0.5 \mathrm{~cm}$ diameter disc of each fungus in the interaction was placed on opposite sides of the plate. The growth 
was measured from the fourth day after inoculation and every week after that for a total of nine weeks. The competition assays continued over a longer period of time than the growth assays, to ensure that the fungi had opportunity to compete fully. Plates were sealed with Parafilm and maintained at $20{ }^{\circ} \mathrm{C}$ in the dark. Measurements were done using Image Tool v3.00 Microsoft $\AA$ and the total area covered by each fungus was calculated.

2.5 Data analysis

An Analysis of Variance (ANOVA) using a General Linear Model (GLM) (SAS version 8.2 (SAS Institute, 2001)) was used to examine differences in total nematode numbers between the nematode source and fungal strain treatments. To analyse the growth of the fungi, an ANOVA using a GLM and a Repeated Measures ANOVA (SAS version 8.2 (SAS Institute, 2001)) was used. STKROMME (SHC du Toit, South African Institute for Statistical Research, HSRC, 1980) was used to fit a Gompertz curve to the growth data.

\section{Results}

3.1 Nematode survival and reproduction assays

The number of nematodes produced per flask ranged from $1.7 \times 10^{5}$ to $4.3 \mathrm{x}$ $10^{6}$, with an average of $1.3 \times 10^{6}$. Considering all nematode sources together, significantly more nematodes were produced on flasks with $A$. areolatum (AUS) $\left(\right.$ Least Squares $(\mathrm{LS})$ mean $=1.5 \times 10^{6}$, range $=1.7 \times 10^{5}$ to $\left.4.3 \times 10^{6}\right)$ than on flasks 
with $A$. areolatum $(\mathrm{KZN})\left(\mathrm{LS}\right.$ mean $=1.1 \times 10^{6}$, range $=3.0 \times 10^{5}$ to $\left.3.4 \times 10^{6}\right)(\mathrm{p}=$ 0.0037). This difference was mainly due to the highly significant difference in numbers of the BRA nematode source on A. areolatum (AUS) (LS mean $=2 \times 10^{6}$, range $=1.1 \times 10^{6}$ to $\left.2.9 \times 10^{6}\right)$ and $A$. areolatum $(\mathrm{KZN})\left(\mathrm{LS}\right.$ mean $=8.4 \times 10^{5}$, range $=$ $3.4 \times 10^{5}$ to $1.6 \times 10^{6}$ ) (Table 1$)$.

Other than the BRA source, none of the other nematode sources showed significant differences in numbers produced on the two A. areolatum strains (Table 1). The number of nematodes produced for the different nematode sources was not significantly different, except of the ARG nematode source, which produced significantly less than the other sources $(p=0.0094)$. None of the nematode sources produced significantly more nematodes on $A$. areolatum $(\mathrm{KZN})$, compared to the KZN nematode source (Table 1).

\subsection{Fungal growth assays}

The growth of the fungi was significantly influenced by time, medium, the fungus species / strain and the interaction between medium and fungus species / strain $(\mathrm{p}<0.0001)$. Growth of all four fungi decreased with decreasing water potential (Figure 1). Amylostereum areolatum (KZN) grew significantly faster than $A$. areolatum (AUS) on MEA ( $\mathrm{p}<0.05$ ), but not on -5 MPa and -10 MPa (Fig. 1). Diplodia pinea and $O$. ips grew significantly faster than $A$. areolatum (AUS) and $A$. areolatum $(\mathrm{KZN})$ on MEA and $-5 \mathrm{MPa}(\mathrm{p}<0.0001)$ (Fig. 1). Diplodia pinea grew faster than A. areolatum (AUS), A. areolatum (KZN) and O. ips on $-10 \mathrm{MPa}(\mathrm{p}<$ 0.05) (Fig. 1). The growth of D. pinea and O. ips slowed down and stopped as it came close to the edge of the Petri dishes (Fig. 1). 

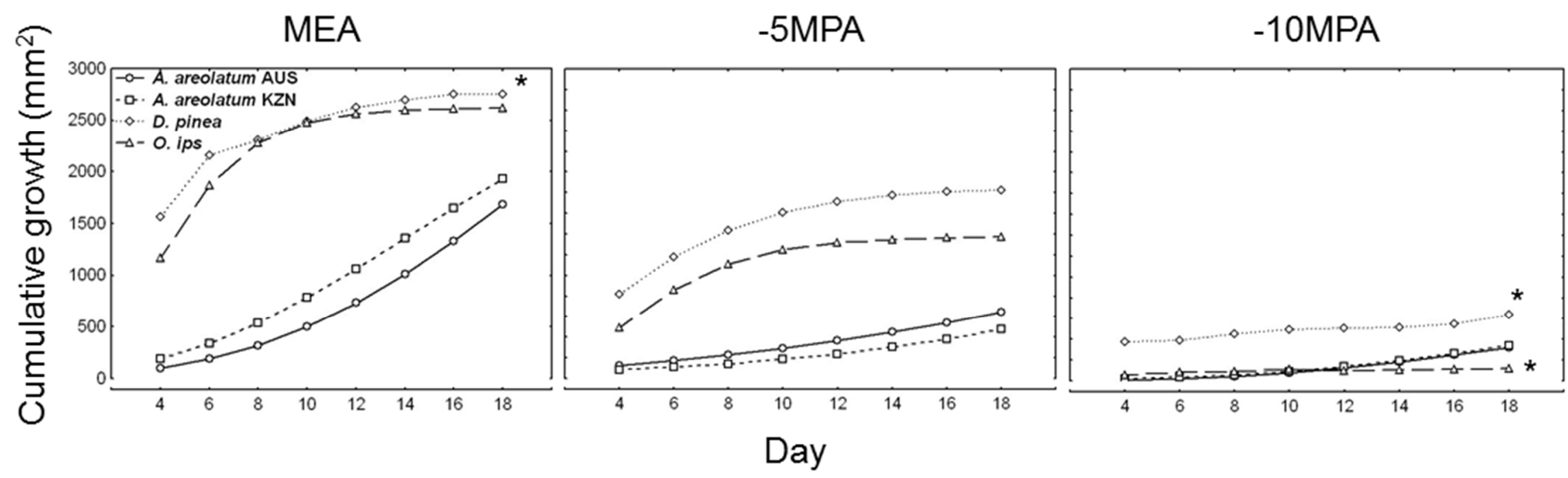

Figure 1. Comparison of the cumulative growth of four fungi, A. areolatum AUS, A. areolatum KZN, D. pinea and O. ips, on three media of different water potential, over an 18 day period. Growth curves that did not fit a Gompertz function are indicated with an asterix (*). 
Table 1. P-value table comparing nematodes produced on $A$. areolatum AUS and $A$. areolatum KZN fungus, on four nematode sources (ARG, BRA, KZN, KZN2). The difference in nematode numbers between treatments was not significantly different (NS), significantly different where $p<0.05(*)$, significantly different where $p<0.01$ $(* *)$, or significantly different where $\mathrm{p}<0.001(* * *)$. LS mean values for the different treatments are indicated.

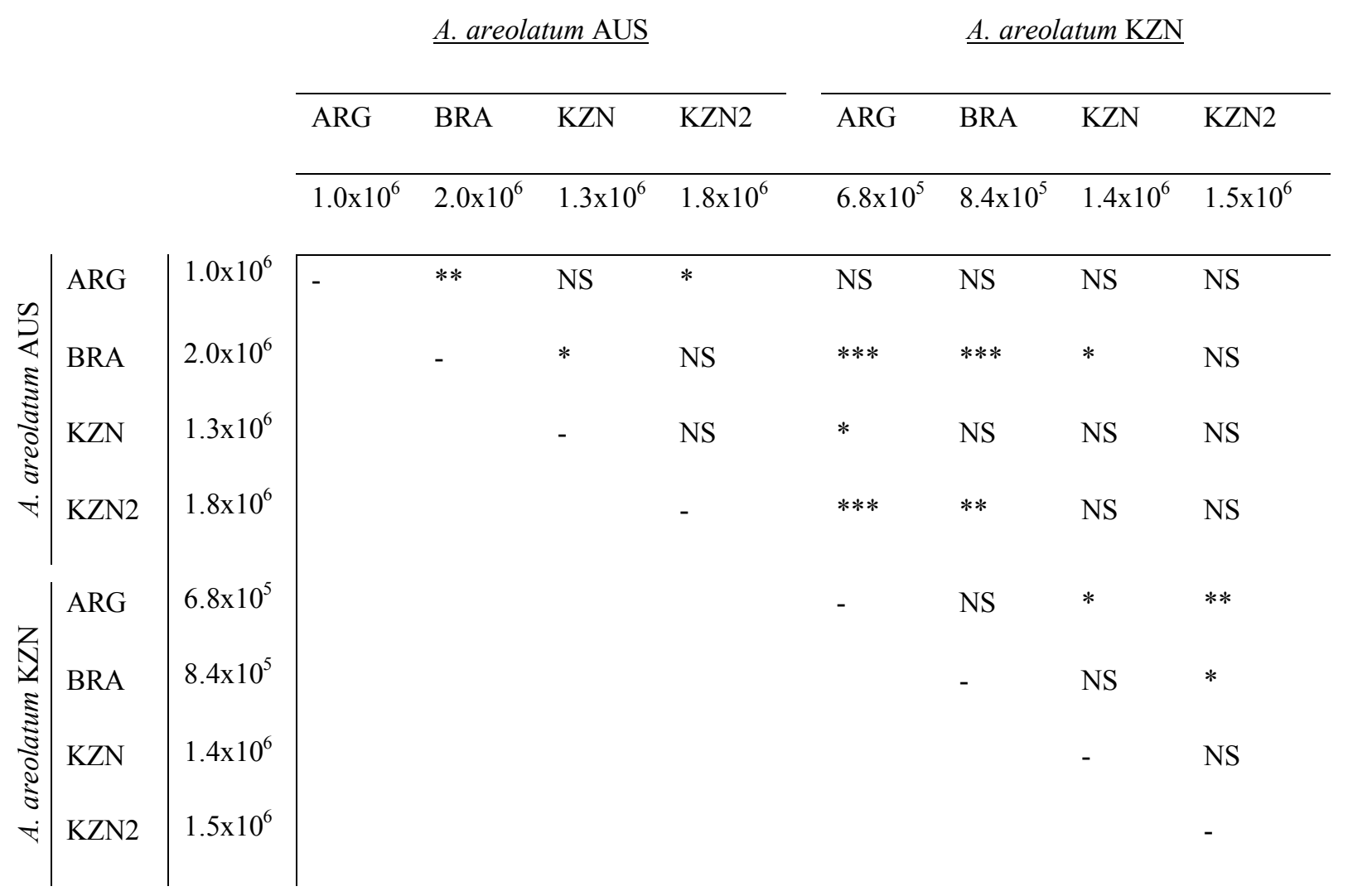




\subsection{Fungal competition assays}

The growth of the fungi in the competition assays was significantly influenced by time and medium $(\mathrm{p}>0.0001)$. There was no clear difference in the competitive interaction of $A$. areolatum (AUS) and $A$. areolatum $(\mathrm{KZN})$ with the two sapstain fungi, D. pinea and $O$. ips (Fig. 2). Diplodia pinea captured more primary resource than $A$. areolatum on all media, but competed increasingly better against $A$. areolatum with decreasing water potential (Fig. 2). Despite the great differences in primary resource capture, $D$. pinea did not replace $A$. areolatum on any medium. A barrier was formed between the two fungi on MEA and -5 MPa, with inhibition of hyphal growth at a distance, resulting in a deadlock between the fungi (Fig 3A-B). On -10 MPa, the growth form of $D$. pinea changed and hyphal growth appeared to stop at the point of contact between the two fungi (Fig 3C).

The competitive ability of $O$. ips against $A$. areolatum decreased with a decrease in water potential (Fig. 2). On MEA, O. ips captured far more primary resource than A. areolatum (Fig 2, Fig 3D). After four weeks a barrier was formed between the fungi, with inhibition at a distance. Ophiostoma ips also captured more primary resource at $-5 \mathrm{MPa}$, but the difference in growth between the two fungi was not as great, and no barrier was observed for the duration of the study (Fig 3E) Amylostereum areolatum captured more primary resource than $O$. ips on $-10 \mathrm{MPa}$ (Fig. 2). At -10 MPa, isolates of O. ips changed in morphology (Fig 3F).

The competitive ability of $O$. ips against $D$. pinea decreased with a decrease in water potential (Fig. 2). On MEA, O. ips initially captured more primary resource than D. pinea. A barrier was formed after three weeks, which inhibited the growth of O. ips (Fig 3G). Diplodia pinea continued to grow, but at the end of the study there 


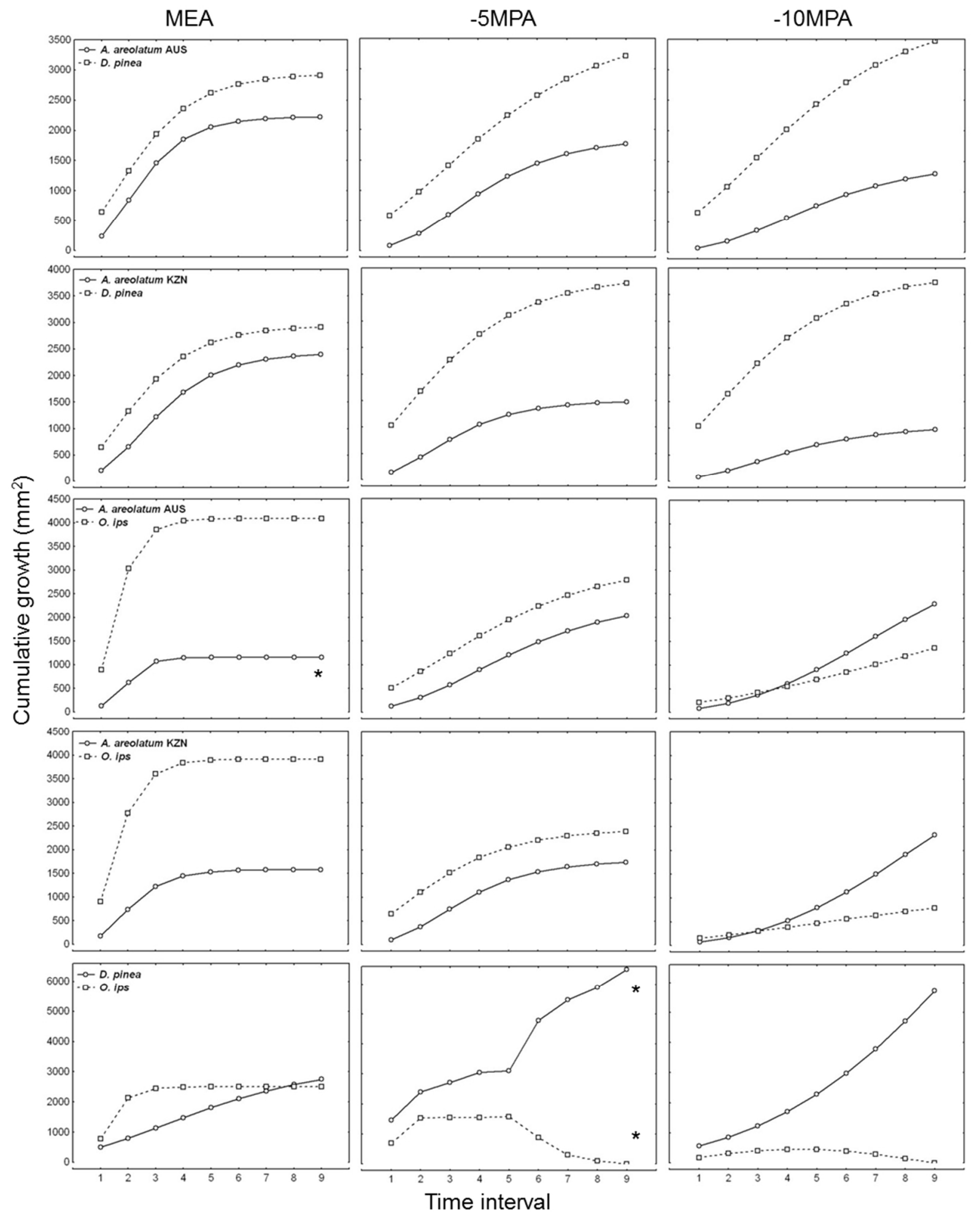

Figure 2. Comparison of the cumulative growth of four fungi, A. areolatum AUS, A. areolatum KZN, D. pinea and $O$. ips, competing with each other on three media of different water potential, over a nine week period. Growth curves that did not fit a Gompertz function are indicated with an asterix (*). 

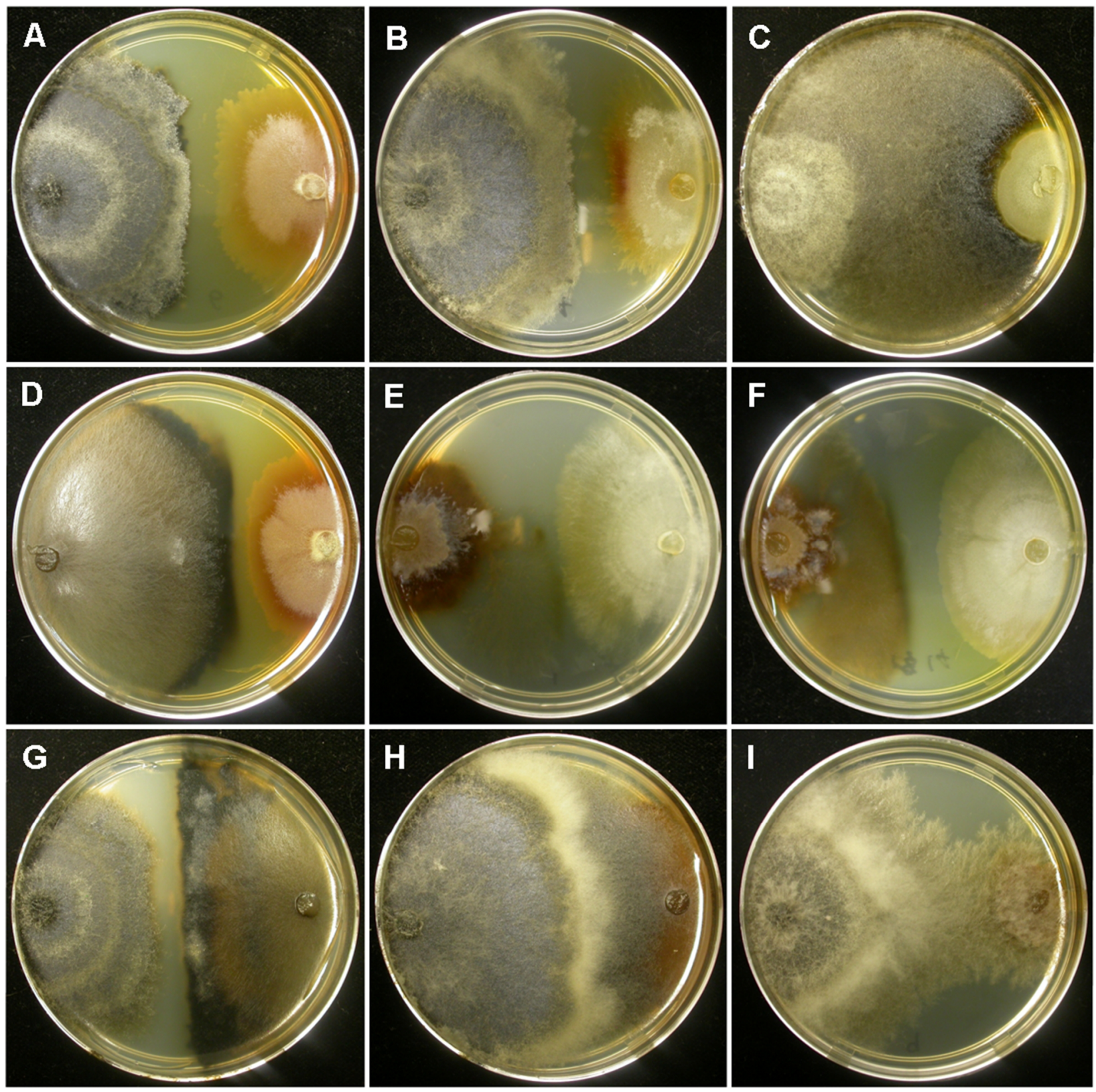

Figure 3. Examples of competitive interactions between the fungi A. areolatum AUS, A. areolatum $\mathrm{KZN}, D$. pinea and $O$. ips. A-C $=D$. pinea (left) competing with $A$. areolatum AUS (right) on MEA, $-5 \mathrm{MPa}$ and $-10 \mathrm{MPa}$ medium, respectively. $\mathrm{D}-\mathrm{F}=D$. pinea (left) competing with $A$. areolatum $\mathrm{KZN}$ (right) on MEA, -5MPa and -10MPa medium, respectively. G-I $=D$. pinea (left) competing with $O$. ips (right) on MEA, $5 \mathrm{MPa}$ and $-10 \mathrm{MPa}$ medium, respectively. Pictures were taken at week seven. 
appeared to be a deadlock between the two fungi. This deadlock situation only occurred in some of the interactions between $D$. pinea and $O$. ips and was thus not evident in Fig. 2 which represented the average growth. On -5 MPa and -10 MPa, $D$. pinea captured more primary resource and replaced O. ips (secondary resource capture) (Fig 2, Fig 3H-I).

\section{Discussion}

This study examined incompatibility between strains of the nematode $D$. siricidicola and the fungal symbiont $A$. areolatum, and competition between $A$. areolatum and sapstain fungi, as possible reasons for the inconsistent control of $S$. noctilio by $D$. siricidicola. The results did not support the hypothesis of incompatibility between nematode and fungal strains, but did support the hypothesis that competitive interactions between $A$. areolatum and sapstain fungi at different water potentials might be involved in the inconsistent control of $S$. noctilio by $D$. siricidicola. Interactions between the nematode, fungi and water availability should thus be considered in current and future biological control efforts against $S$. noctilio.

Deladenus siricidicola released in South Africa as a biological control agent against $S$. noctilio was able to survive and reproduce on the South African field strain of $A$. areolatum, introduced naturally with $S$. noctilio, at levels comparable to its survival on the genetically different Australian strain (Slippers et al., 2001) used to raise the nematodes. The survival and reproduction of the nematode was also comparable to that of the nematode strain that has been introduced in Brazil and Argentina. The nematodes released in Brazil and Argentina have given parasitism levels of over $70 \%$ in their respective countries (Iede et al., 1998; V. Klasmer, 
personal communication), where they are associated in the field with the same strain of $A$. areolatum introduced into South Africa with S. noctilio (Slippers et al., 2001). The survival and reproduction of all the nematode sources used for biological control in southern hemisphere countries on the strain of $A$. areolatum occurring with the wasp under field situations in South Africa and South America was comparable. This indicates that incompatibility between $A$. areolatum $(\mathrm{KZN})$ and the Kamona strain of D. siricidicola is an unlikely explanation for the low inoculation success in the summer rainfall areas of South Africa.

The KZN2 nematodes reared on A. areolatum KZN for multiple generations did not give rise to higher numbers of nematodes on $A$. areolatum $\mathrm{KZN}$ in this study. This suggests that efforts to breed for greater survival and reproduction on the $A$. areolatum (KZN) fungus using the Kamona strain of $D$. siricidicola are unlikely to be successful. It is not clear why the nematodes sourced from Brazil gave rise to significantly higher numbers on $A$. areolatum (AUS) than on $A$. areolatum (KZN), but this result highlights the possibility of increased fitness of specific nematode strains on specific fungal strains. Further investigations to understand the behaviour of nematode strains in different environments, as well as their comparable fitness on different $A$. areolatum strains are clearly warranted.

Amylostereum areolatum generally grew more slowly than the sapstain fungi D. pinea and $O$. ips, on the media used in this study. However, the $S$. noctilio symbiont showed strong defence capabilities and was never replaced by the sapstain fungi. Amylostereum areolatum defended its food resource through the formation of an antagonistic barrier zone some distance from the competing fungi. Alternatively, the fungus produced a stationary barrier zone of mycelium resistant to invasion, at the point of mycelial contact. These forms of combative interactions are well known in 
fungi. Boddy (2000) stated that antagonism at a distance, hyphal interference, mycoparasitism and gross mycelial contact were the main forms of combative interactions. The outcomes of these interactions may result in replacement of one fungus with another or a deadlock between the two species, as observed between $A$. areolatum and the sapstain fungi.

The growth rate and competitive ability of the two A. areolatum strains in this study was very similar on most media. There were only differences on the media with the highest water potential (MEA), where the South African strain grew faster. Inoculation success of $D$. siricidicola is particularly poor at low moisture availability (Hurley et al., 2008), but there were no significant differences in competitive ability of the two A. areolatum strains on media with lower water potentials. These results indicate that the difference in the competitive ability of the two A. areolatum strains is unlikely to explain the low levels of inoculation success in the summer rainfall areas of South Africa.

Reduced water potential decreased the growth of all of the fungi considered in this study, including the $S$. noctilio symbiont, A. areolatum, and the sapstain fungi that it encounters in woodwasp-infested trees. For A. areolatum, this is consistent with the experience of Boddy (1983) who noted that wood decay Basidiomycetes generally do not grow well below -4.4 MPa. Although $A$. areolatum growth decreased at lower water potentials, the fungus did not cease to grow and was able to compete for resources with the sapstain fungi. In contrast to $A$. areolatum, $D$. pinea displayed its best growth on the media having low water potential and this is consistent with the fact that some Ascomycetes are favoured by low water potentials (Boddy, 2000). However, O. ips showed very poor growth and competitive ability at low water potentials, to such an extent that it was replaced by $D$. pinea. This result is similar to 
that of Klepzig et al. (2004) who found that the related Ophiostoma sp., Ophiostoma minus (Hedgcock) H. and P. Sydow had decreased competitive ability on media having low water potential.

The growth and competitive ability of the fungi examined in this study offer important insights into factors that might affect the establishment of $A$. areolatum in the field and consequently the survival of $D$. siricidicola. Amylostereum areolatum is likely to be able to grow in the low moisture conditions that the nematodes experience in the summer rainfall area of South Africa (Hurley et al., 2008). The growth under these conditions would be slow, and most of the resource could then be captured by D. pinea, which is uniformly present in Pinus spp. in South Africa (Swart et al., 1985; Wingfield and Swart, 1994). However, A. areolatum would be able to defend its resource, thus securing the food source of the $S$. noctilio larvae and D. siricidicola, which would have entered the tree naturally with $A$. areolatum. Artificial inoculations with $D$. siricidicola occur some time after the tree is attacked by $S$. noctilio, as symptoms of attack must first be observed (Haugen et al., 1990). These trees would have already lost moisture since the attack and at that time $D$. pinea infection is likely to be well established. This could decrease the survival of the inoculated nematodes in the tree, as they still need to locate the areas of $A$. areolatum establishment.

The suggestion that competitive interactions between sapstain fungi and $A$. areolatum could have greater significance on inoculation success than on natural parasitism of $D$. siricidicola is supported by other data. Although high levels of parasitism have been obtained in South America, results have been variable, and Hurley et al. (2007) suggested that inoculation success is low, but that natural parasitism levels can be high. Similarly, inoculations in the Cape province of South Africa originally gave poor results $(22.6 \%)$, but natural spread of the nematode 
increased parasitism to $96.1 \%$ just two years later (Tribe and Cillié, 2004). Recent data from the summer rainfall areas also indicates that natural parasitism is increasing (above 50\% in some sites, in the bottom section of the trees), although inoculation success still remains poor (Brett Hurley, unpublished data)

The results of laboratory growth and competition assays with fungi, such as those obtained in this study, should be interpreted with caution. While they might reflect the field environment, this may not always be the case. For example, the outcome of interactions in the natural environment can be influenced by the microclimate, the size and quality of the resource, temperature, and the presence of multiple competing fungi (Boddy, 2000). In our study we examined the influence of one variable, water potential, but other variables are likely to also influence the outcome of the interactions studied. While it would be difficult to consider the interactions of different fungi and nematodes in wood and under natural conditions, such studies could provide further insight into the establishment of $A$. areolatum in the field.

\section{Acknowledgements}

We thank Wilhelm de Beer (FABI, South Africa) for his assistance in isolating O. ips, Tuan Duong (FABI, South Africa) for confirming the identification of the $O$. ips isolate based on DNA sequence comparisons, and Wubetu Bihon (FABI, South Africa) for providing the isolate of $D$. pinea, also identified using DNA sequences. We also thank Hardus Hatting (FABI, South Africa) for his assistance with rearing laboratory cultures of $D$. siricidicola. The USDA Forest Service, Southern Research Station, Forestry South Africa (FSA), the Department of Water Affairs and Forestry, 
the University of Pretoria and the THRIP initiative of the Department of Trade and Industry (DTI), South Africa, provided financial support for this study.

\section{References}

Bedding R.A., 1968. Deladenus wilsoni n.sp.and D. siricidicola n.sp.

(Neotylenchidae), entomophagous nematodes parasitic in siricid woodwasps. Nematol. 14, 515-525.

Bedding R.A., 1972. Biology of Deladenus siricidicola (Neotylenchidae) an entomophagous-mycetophagous nematode parasitic in siricid woodwasps. Nematol. $18,482-493$.

Bedding R.A., Akhurst R.J., 1978. Geographical distribution and host preferences of Deladenus species (Nematoda: Neotylenchidae) parasitic in siricid woodwasps and associated hymenopterous parasitoids. Nematol. 24, 286-294.

Bedding R.A., Akhurst R.J., 1974. Use of the nematode Deladenus siricidicola in the biological control of Sirex noctilio in Australia. J. Aust. Entomol. Soc. 13, 129-135.

Bedding R.A., Iede E.T., 2005. Application of Beddingia siricidicola for Sirex woodwasp control. In: Grewal P.S., Ehlers R., Shapiro-Ilan D.I (Eds.), Nematodes as Biocontrol Agents. CAB International, Wallingford, UK, pp. 385-400.

Bleiker K.P., Six D.L., 2009. Effects of water potential and solute on the growth and interactions of two fungal symbionts of the mountain pine beetle. Mycol. Res. 113, $3-15$.

Boddy L., 1983. The effect of temperature and water potential on the growth rate of wood-rotting basidiomycetes. Trans. Br. Mycol. Soc. 80, 141-149. 
Boddy L., 2000. Interspecific combative interactions between wood-decaying basidiomycetes. FEMS Micr. Ecol. 31, 185-194.

Carnegie A.J., Elderidge R.H., Waterson D.G., 2005. History and management of Sirex wood wasp in pine plantations in New South Wales, Australia. N.Z. J. For. Sci. 35, 3-24.

Cartwright K.S.T.G., 1929. Notes on fungus associated with Sirex cyaneus. Ann. Appl. Biol. 16, 182-187.

Cooke R.C., Rayner A.D.M., 1984. Ecology of saprotrophic fungi. Longman Group Limited, England.

Coutts M.P., 1969. The mechanism of pathogenicity of Sirex noctilio on Pinus radiata II. Effects of S. noctilio mucus. Aust. J. Biol. Sci. 22, 1153-1161.

de Groot P., Nystrom K., Scarr T., 2007. Discovery of Sirex noctilio (Hymenoptera: Siricidae) in Ontario, Canada. Great Lakes Entomol. 39, 49-53.

Gilbert J.M., Miller L.W., 1952. An outbreak of Sirex noctilio in Tasmania Aust. J. Biol. Sci. 22, 905-914.

Haugen D.A., 1990. Control procedures for Sirex noctilio in the Green Triangle: Review from detection to severe outbreak (1977-1987). Aust. For. 53, 24-32. Haugen D.A., Bedding R.A., Underdown M.G., Neumann F.G., 1990. National strategy for control of Sirex noctilio in Australia. Aust. For. Grower.

Hoebeke E.R., D.A., H., Haack R.A., 2005. Sirex noctilio: discovery of a Palearctic siricid woodwasp in New York. Newsl. Michigan Entomol. Soc. 50, 24-25.

Hurley B.P., Slippers B., Croft P.K., Hatting H.J., van der Linde M., Morris A.R., Dyer C., Wingfield M.J., 2008. Factors influencing parasitism of Sirex noctilio (Hymenoptera: Siricidae) by the nematode Deladenus siricidicola (Nematoda: Neotylenchidae) in summer rainfall areas of South Africa. Biol. Cont. 45, 450-459. 
Hurley B.P., Slippers B., Wingfield M.J., 2007. A comparison of control results for the alien invasive woodwasp, Sirex noctilio, in the southern hemisphere. Agric. For. Entomol. 9, 159-171.

Iede E.T., Penteado S.R.C., Schaitza E.G., 1998. Sirex noctilio problem in Brazil detection, evaluation and control. In: Iede E., Schaitza E.G., Penteago R., R., R., Murphy T. (Eds.), Training in the control of Sirex noctilio by use of natural enemies. USDA Forest Service, pp. 45-52.

King J.M., 1966. Some aspects of the biology of the fungal symbiont of Sirex noctilio. Aust. J. Bot. 14, 25-30.

Klasmer P., Fritz G., Corley J., Botto E., 1998. Current status of research on Sirex nictilio F. in the Andean-Patagonia region in Argentina. In: Iede E., Shaitza E., Penteado S., Readon R., Murphy T. (Eds.), Training in the control of Sirex noctilio by use of natural enemies. USDA Forest Service, pp. 89-90.

Klepzig K.D., Flores-Otereo J., Hofstetter R., Ayres M., 2004. Effects of available water on growth and competition of southern pine beetle associated fungi. Mycol. Res. 108, 183-188.

Klepzig K.D., Wilkens R.T., 1997. Competitive interactions among symbiotic fungi of the southern pine beetle. Appl. Environ. Microbiol. 63, 621-627.

Maderni J.F.P., 1998. Sirex noctilio F.: present status in Uruguay. In: Iede E., Shaitza E., Penteado S., Reardon R., Murphy T. (Eds.), Training in the control of Sirex noctilio by use of natural enemies. USDA Forest Service, pp. 81-82.

Miller D., Clarke A.F., 1935. Sirex noctilio (Hym.) and its parasites in New Zealand. Bull. Entomol. Res. 26, 149-154. 
Nielsen C., Williams D.W., Hajek A.E., 2009. Putative source of the invasive Sirex noctilio fungal symbiont, Amylostereum areolatum, in the eastern United States and its association with native siricid woodwasps. Mycol. Res. 113, 1242-1253.

Rayner A.D.M., Webber J.F., 1986. Interspecific mycelial interactions - an overview. In: Jennings D.H., Rayner A.D.M. (Eds.), The ecology and physiology of the fungal mycelium. Cambridge University Press, Great Britain, pp. 383-418.

SAS Institute, 2001. User guide, SAS. SAS Institute Inc., Cary NC, USA.

Shearer C.A., 1995. Fungal competition. Can. J. Bot. 73, s1259-s1264.

Slippers B., Wingfield B.D., Wingfield M.J., 2001. Population structure and possible origin of Amylostereum areolatum in South Africa. Plant Pathol. 50, 206-210.

Slippers B., Wingfield B.D., Wingfield M.J., Coutinho T.A., 2003. The genus Amylostereum and its association with woodwasps: a contempary review. S. Afr. J. Sci. 99, 70-74.

Spradbery J.P., 1973. A comparative study of the phytotoxic effects of siricid woodwasps on conifers. Ann. Appl. Biol. 75, 309-320.

Spradbery J.P., Kirk A.A., 1978. Aspects of the ecology of siricid woodwasps (Hymenoptera: Siricidae) in Europe, North Africa and Turkey with special reference to the biological control of Sirex noctilio F. in Australia. Bull. Entomol. Res. 68, 341-359.

Swart W.J., Knox-Davies P.S., Wingfield M.J., 1985. Sphaeropsis sapinea with special reference to its occurence on Pinus spp. in South Africa. S. Afr. For. J. 35, $1-8$.

Swart W.J., Wingfield M.J., 1991. The biology and control of Sphaeropsis sapinea in South Africa. Plant Dis. 75, 761-766. 
Talbot P.H.B., 1977. The Sirex - Amylostereum - Pinus association. Annu. Rev. Phytopathol. 15, 41-54.

Tribe G.D., 1992. Colonization sites on Pinus radiata logs of the bark beetles, Orthotomicus erosus, Hylastes angustatus and Hylurgus ligniperda (Coleoptera: Scolytidae). J. Entomol. Soc. S. Afr. 1, 77-84.

Tribe G.D., 1995. The woodwasp Sirex noctilio Fabricius (Hymenoptera: Siricidae), a pest of Pinus species, now established in South Africa. Afr. Entomol. 3, 215-217.

Tribe G.D., Cillie J.J., 2004. The spread of Sirex noctilio Fabricius (Hymenoptera: Siricidae) in South African pine plantations and the introduction and establishment of its biological control agents. Afr. Entomol. 12, 9-17.

Whiting E.C., Rizzo D.M., 1999. Effect of water potential on radial colony growth of Armillaria mellea and A. gallica in culture. Mycologia 91, 627-635.

Wingfield M.J., Swart W.J., 1994. Intergrated management of forest tree diseases in South Africa. For. Ecol. Manag. 65, 11-16.

Yemshanov D., McKenney D.W., de groot P., Haugen D., Sidders D., Joss B., 2009. A bioeconomic approach to assess the impact of an alien invasive insect on timber supply and harvesting: a case study with Sirex noctilio in eastern Canada. Can. J. For. Res. 39, 154-168.

Zhou X.D., de Beer W., Wingfield M.J., Wingfield B.D., 2001. Ophiostomatoid fungi associated with three pine infested bark beetles in South Africa. Sydowia 53, 290300. 